\title{
Virulence Factors and Prevalence of Udder's Pathogens in Dairy Cows during the Peripartal Period
}

\author{
Zuzana Farkašová $^{1 *}$, František Zigo ${ }^{2}$ and Zuzana Lacková ${ }^{3}$ \\ ${ }^{1}$ Department of Nutrition and Animal Husbandry, University of Veterinary Medicine and Pharmacy \\ Košice, Slovakia \\ *Corresponding author's mail: zuzana.lackova [AT] uvlf.sk \\ ${ }^{2}$ Department of Nutrition and Animal Husbandry, University of Veterinary Medicine and Pharmacy \\ Košice, Slovakia \\ Email: frantisek.zigo [AT] uvlf.sk \\ ${ }^{3}$ Department of Nutrition and Animal Husbandry, University of Veterinary Medicine and Pharmacy \\ Košice, Slovakia \\ Email: zuzana.farkasova [AT] uvlf.sk
}

\begin{abstract}
Data presented in this study described the prevalence of udder pathogens and presence of virulence factors in staphylococci isolated from mastitis in dairy cows. The practical part of study was realized in five different dairy herds of Slovak spotted cattle breed located in Eastern Slovakia with conventional (non-organic) farming. At the beginning of lactation (during first two months after calving) were comprehensively investigated 960 cows from monitored herds. The comprehensive examination included clinical examination, sensory analysis of milk from fore stripping of each udder quarter, followed by assessment of the California mastitis test (CMT) and laboratory analyses of bacteria pathogens. Screening the health status of the mammary gland revealed that 314 cows (32.7\%) had positive CMT score (1-3) for one or more quarters. Out of 230 infected milk samples, representing $24.0 \%$ of all dairy cows examined, were the most commonly isolated staphylococci (59.1\% of positive findings), followed by $E$. coli (11.3\%), streptococci Str. uberis (9.1\%), Str. agalactiae (3.4\%), and enterococci $(6.1 \%)$. From 136 isolates of coagulase negative stafylococci (98 isolates) and $S$. aureus (38 isolates) were detected some virulence factors such as production of hemolysins (lysines $\beta$ and $\delta$ ), gelatinase, biofilm, and hydrolyze of DNA. Isolated S. aureus, S. chromogenes and $S$. warneri had the most numerous representation of detected virulence factors, as demonstrated by the increased incidence of clinical forms of mastitis compared to less virulent strains.
\end{abstract}

Keywords— Dairy Cows, Peripartal Period Mastitis, Biofilm, DNAse

\section{INTRODUCTION}

Bovine mastitis, the result of complex interactions among the host, environment and infectious agents. It is one of the most prevalent diseases of dairy cattle, and affects world dairy production, decreasing the quantity and quality of milk products. Mastitis differs from most other animal diseases in that several diverse kinds of bacteria are capable of infecting the udder. These pathogens invade the udder, multiply, and produce harmful substances that result in inflammation $[3,28]$.

To date, over 137 different organisms have been identified as being causative agents of bovine mastitis, including bacteria, viruses, mycoplasma, yeasts and algae but bacteria remain the principle causative agents (95\% of all IMI) of such complex. Generally, every mastitis case is considered to be caused by one primary pathogen, because usually only one bacterial species is identified in milk samples from diseased glands. Nevertheless, simultaneous infections by two different pathogen species are not rare, and three pathogens may be found in a small proportion of cases [1,26].

The bacteria causing the most common forms of mastitis may be considered within two groups. Contagious pathogens (e.g. Staphylococcus aureus, Streptococcus agalactiae or Streptococcus dysgalactiale). These organisms can survive and grow within the MG so that transmission of infection from infected to uninfected quarters and from cow to cow is most likely to occur during milking. Environmental pathogens thrive in the environment especially where cows' faeces are involved [6, 32].

In recent years, $S$. aureus and CoNS belong of the most common microorganisms causing mastitis in dairy cows. The manifestations of the inflammatory process caused by staphylococci are different, as they depend on the degree of reaction of the udder tissue to injury or infection. The clinical manifestations of mammary gland (MG) inflammation as well as its further course depend on the interplay between the innate resistance and adaptive immunity of the dairy cow and the concentration, and virulence of staphylococcal strains [16]. 
Generally, if the $S$. aureus is able to penetrate the teat in sufficient numbers the disease taken one of two clinical forms of IMI. Peracute staphylococcal mastitis can occur rarely, but especially in early lactation when the immune defenses of the cow are depressed. Although the cow with peracute $S$. aureus infection can be saved by an effective antibiotic, if caught in time, the quarter is almost invariably lost [4, 17].

The more common form of $S$. aureus infection is less severe but chronic. The affected cow may not appear ill and the affected quarter may not be painful. The foremilk may or may not show abnormalities. Treatment of $S$. aureus infection is complicated by the fact there are many strains and more and more of them are becoming resistant to more and more of the antibiotics within the veterinary armory. Their increased resistance is also due to the fact that, in addition to treating clinical cases of IMI, the common routine on farms is to dry dairy cows across the board with antibiotics. The studies confirm the increased resistance of both $S$. aureus and CoNS to those antibiotics, that are part of intramammary applicators used to treatment of dry dairy cows $[10,11]$.

Of this group, E. coli is the most important with multiple strains of varying pathogenicity for animals and humans. Others include Streptococcus uberis, coagulase-negative staphylococci (CoNS), Corynebacterium spp., Pseudomonas spp., Serratia spp., Proteus spp., Pasteurella spp., Listeria spp., Leptospira spp., Yersinia spp., Enterobacter spp., Brucella spp. and Mycobacterium spp. [10, 27].

On the other side, CoNS are considered to be minor pathogens in dairy mastitis however, there is increasing work by authors to emphasize their role in the development of MG inflammation [8, 18, 29]. The increase of their occurrence in dairy farms occurs after the reduction of the occurrence of the main pathogens, the CoNS that are present are characterized by increased resistance to commonly used antibiotics and disinfectants. Compared to S. aureus, CoNS usually have a lower proportion of virulence factors but their essential factor of pathogenicity is the production of a biofilm and thus resist the applied disinfection and sanitation procedures. In addition, in other study, confirmed that the CoNS (S. epidemidis, S. saprophyticus, S. hominis and S. aerletae isolated from mastitic cows, were resistant to the antibiotics used and were able to produce some of the staphylococcal enterotoxins [18]. Other authors consider the ability to produce biofilm and lysine to be an important virulence factors that are responsible for the development of clinical forms of mastitis [8, 29].

The aim of this study was to monitor the occurrence of udder pathogens. Particularly in isolated staphylococci were determined the presence of selected virulence factors (formation of hemolysins, gelatinase, biofilm, hydrolyze DNA,) and their effect on the severity of mastitis in dairy cows.

\section{MATERIAL AND METHODOLOGY}

\subsection{Monitored herds and udder health examination}

The practical part of study was realized in five different dairy herds located in Eastern (4 herds) and Western ( 1 herd) Slovakia with conventional (non-organic) farming. Herds size ranged from 150 to 300 dairy cows of Slovak spotted breed between $1^{\text {st }}-4^{\text {th }}$ lactation were used. From all monitored dairy farms, were investigated 270 cows from first, 215 cows from second, 175 cows from third, 153 cows from fourth, and 147 cows from fifth herd. Clinical examination of selected dairy cows, was carried out gradually with the collection of a mixed milk sample, after their transfer to the production group during the first two months of lactation.

A thorough evaluation of udder health included clinical examination, sensory analysis of milk from fore stripping of each udder quarter, followed by assessment of the California mastitis test (CMT) (Indirect Diagnostic Test, Krause, Denmark). Milk from every quarter was mixed with the reagent, and the result was scored as negative, trace, or positive (score 1-3) depending on the formation of gel in the milk sample according to Tančin [25].

Subsequently, from the 960 examined cows were selected 314 cows with CMT score trace positive. From selected cows were aseptically collected 314 mixed milk samples for bacteriological cultivation in accordance with the guidelines of the [19]. The samples were cooled to $4{ }^{\circ} \mathrm{C}$ and immediately transported to the laboratory and analyzed on the following day.

\subsection{Bacteriological culture}

Milk inoculum $(10 \mu \mathrm{l})$ of each sample was aerobically cultivated on the plates with $5 \%$ blood agar, at $37{ }^{\circ} \mathrm{C}$ for $24 \mathrm{~h}$.

The primocultivation and identification of Staphylococcus spp. was carried out according to the assessment growth of suspected bacteria on nutrient agars (5\% of blood Agar, $\mathrm{N}^{\circ} 110$, Baird-Parker agar, Brilliance UTI Clarity Agar (OXOID

Figure 1. Biofilm production on Congo Red Agar for staphylococcal detection
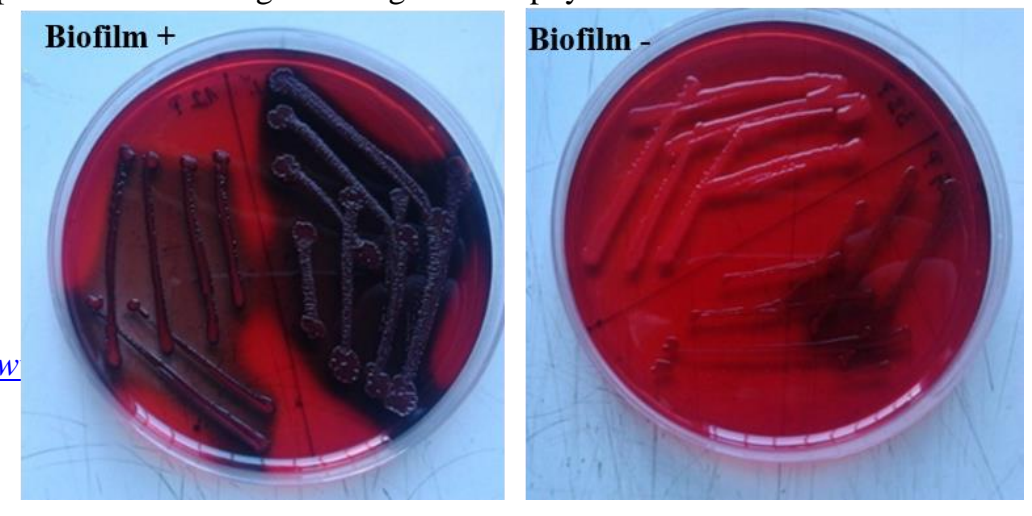
Ltd., Basingstoke, Hants, UK). The pigment formation, catalase positivity, Gram positivity, creation of free or coupled coagulase, the ability of staphylococci to hydrolyze DNA, production of hemolysins, gelatinase and biofilm (Fig. 1) were determined according to studies [9, 20,30]. Streptococci were determined by colony morphology and CAMP-reaction according to Holko [10]. Enterococci were confirmed by Gram-staining and growth of typical colonies on SlaBa-plates (Slanetz \& Bartley, Medium, Oxoid Ltd., Basingstoke, England). A milk sample was classified as positive if more than three colonies from one type of colony-forming unit (CFU) of S. aureus or Str. agalactiae was isolated. For other bacteria, the presence of more than five CFUs was needed for positive classification. Samples were classified as contaminated if three or more bacterial types were isolated from one milk sample and growth of a major udder pathogen was not identified. The identification of each species was made by Staphy test, Strepto test, and resp. Entero test using the software TNW Pro 7.0 (Erba-Lachema, Brno, Czech Republic) with a probability of correct designations of the kind above $90 \%$.

$$
3,44
$$

\subsection{Statistical analysis}

Data were entered in to Microsoft Excel 2007® (Microsoft Corp., Redmond, USA) and analyzed using Excel, State 11, and SPSS version 20 (IBM Corp., Armonk, USA). The dependence of production of virulence factors in the four most frequently isolated bacterial pathogens among the type of mastitis in cows were statistically analysed using the Chisquare test [13]. The dependence of the individual signs was tested at a significance level $\alpha=0.05$, with critical value $=$ 7.815 .

\section{RESULTS AND DISCUSSION}

An examination of five dairy cow herds showed, that from the 960 dairy cows examined during the first two months of lactation, 314 cows $(32.7 \%)$ had CMT score (1-3) for one or more quarters. Of the mixed milk samples taken from selected dairy cows based on CMT scores, 230 were $(73.2 \%)$ identified bacterial agents of mastitis causing a clinical or subclinical form of mastitis, and $84(26.8 \%)$ samples were identified as negative or contaminated. The results of cultivation of microorganisms are shown in Table 1. Out of 230 infected milk samples (23.9\%) of all dairy cows examined, and $73.2 \%$ of the samples taken were the most commonly isolated staphylococci. Mixed infection of two pathogens was identified in 16 cases with the combination of a major udder pathogen. The CoNS represented the most commonly detected bacteria (42.6\% of positive findings); S. aureus (16.5\%) were the second most abundant pathogens followed by E. coli (11.3\%), streptococci (Str. uberis: $9.1 \%$, Str. agalactiae (3.4\%) and enterococci $(6.1 \%)$.

Table 1: Pathogens isolated from milk samples of four monitored dairy herds

\begin{tabular}{lcccc}
\hline \multicolumn{1}{c}{ Pathogens } & $\begin{array}{c}\text { Number } \\
\text { of isolates }\end{array}$ & $\begin{array}{c}\boldsymbol{\%} \\
(\mathrm{n}=230)\end{array}$ & $\begin{array}{c}\text { Clinical IMI }_{\mathbf{1}} \\
\mathbf{( n = 2 3 0 )}\end{array}$ & $\begin{array}{c}\text { Subclinical IMI }^{\mathbf{1}} \\
\mathbf{\%}(\mathrm{n}=230)\end{array}$ \\
\hline CoNS & 98 & 42.6 & 17.4 & 25.2 \\
\hline S. aureus & 38 & 16.5 & 10.0 & 6.5 \\
\hline Escherichia coli & 26 & 11.2 & 3.0 & 8.1 \\
\hline Streptococcus uberis & 21 & 9.1 & 6.1 & 3.0 \\
\hline Streptococcus agalactiae & 8 & 3.4 & 3.0 & 0.4 \\
\hline Streptococcus spp. & 10 & 4.3 & 1.7 & 2.6 \\
\hline Enterococcus spp. & 14 & 6.1 & 2.2 & 3.9 \\
\hline Mixed infection & 16 & 6.9 & 1.3 & 5.6 \\
\hline Total & $\mathbf{2 3 0}$ & $\mathbf{1 0 0}$ & $\mathbf{4 4 . 7}$ & $\mathbf{5 5 . 5}$
\end{tabular}

Our results are consistent with the similar study, which recorded a high incidence of CoNS and S. aureus isolated from milk samples during the examination of 42 dairy farms in the west of Slovakia. The CoNS represented $35.9 \%$ of positive findings and were the most commonly detected bacteria [10].

Among the most serious causative agents of mastitis was S. aureus, which was isolated in 23 clinical and 15 subclinical cases of mastitis. Eight species were isolated from CoNS, with the following recorded as the most numerable species: S. chromogenes (22.4\%), S. warneri (20.4\%), S. xylosus (18.4\%), S. epidermidis (9.1\%) and S. haemolyticus $(7.1 \%)$. The representation of CoNS on the individual forms of IMI was different. Most frequently were detected cases of subclinical mastitis (58), caused predominantly by S. warneri, S. xylosus and S. epidermidis. Clinical mastitis were detected in 40 cases, caused by $S$. chromogenes, S. haemolyticus, S. warneri, and S. xylosus.

In compare to our results the researchers reported, that the S. haemolyticus, S. chromogenes, S. warneri and S. xylosus were isolated as dominant strains of CoNS isolated from mastitis in cows. CoNS was mainly due to clinical mastitis associated with significantly reduced milk production, an increase in SCC [23, 24]. 
For the individual virulence factors (Table 2), co-production of lysines $\beta$ and $\delta$ observed in 7 species, single lysine $\delta$ in nine species of staphylococci. Production of DNAse was detected in S. aureus, S. chromogenes, S. warneri, S. xylosus, and $S$. haemolyticus as well as production of gelatinase, except for $S$. xylosus and $S$. haemolyticus. The stafylococci $S$. aureus, S. chromogenes and $S$. warneri had most numerous representation of virulence factors (production of lysines, gelatinase and biofilm, the ability to hydrolyze DNA) what are resulted as increasing incidence of clinical cases of mastitis in compare to less virulent strains. From all 40 clinical IMI, in 35 cases the production of lysines, in 23 hydrolysis of DNA, 17 cases with production of gelatinase, and 33 cases with biofilm production were detected. Totally, the production of biofilm we found in 50 isolates, whereas in S. capitis the production of biofilm has not been detected. On the significance level of $\alpha=0.05$ was confirmed the independence the production of virulence factors on type of mastitis in cows, in four strains of staphylococci (S. aureus, S. chromogenes, S. warneri, S. xylosus).

Table 2: The role of CoNS in severity of mastitis and the occurrence of selected virulence factors

\begin{tabular}{|c|c|c|c|c|c|c|}
\hline $\begin{array}{l}\text { Staphylococcus } \\
\text { spp./number }\end{array}$ & $\mathrm{IMI}^{1} /$ number & hemolysins ${ }^{2}$ & DNAse ${ }^{3}$ & gelatinase & biofilm & $\begin{array}{c}\text { Test* } \\
\text { G }\end{array}$ \\
\hline \multirow{2}{*}{ S. aureus (38) } & clinical (23) & $9 \alpha+\beta / 7 \alpha / 4 \delta$ & 14 & 11 & 12 & \multirow[t]{2}{*}{$1.089 *$} \\
\hline & subclinical (15) & $3 \alpha+\beta / 4 \alpha$ & 8 & 7 & 5 & \\
\hline \multirow{2}{*}{$\begin{array}{l}\text { S. chromogenes } \\
\text { (22) }\end{array}$} & clinical (13) & $4 \beta+\delta / 4 \delta$ & 3 & 4 & 7 & \multirow[t]{2}{*}{$0.332 *$} \\
\hline & subclinical (9) & $2 \delta$ & 1 & 1 & 3 & \\
\hline \multirow{2}{*}{ S. warneri (20) } & clinical (9) & $2 \beta+\delta / 4 \delta$ & 2 & 2 & 5 & \multirow[t]{2}{*}{$1.578^{*}$} \\
\hline & subclinical (11) & $3 \beta+1 \delta$ & 2 & 0 & 2 & \\
\hline \multirow{2}{*}{ S. xylosus (18) } & clinical (8) & $2 \beta+1 \delta / 3 \delta$ & 2 & 0 & 5 & \multirow[t]{2}{*}{$1.601 *$} \\
\hline & subclinical (10) & $2 \beta+1 \delta$ & 0 & 0 & 4 & \\
\hline
\end{tabular}

Biofilm production by the staphylococcal strains is consider an important virulence factor responsible for adhesion of these microorganisms with living or non-living surfaces [22].

The bacteria carrying this typical peculiarity are highly resilient to antibiotics. The intramammary infection due to biofilm producers $S$. aureus or CoNS is difficult to treat even with intramammary antibiotics so proper considerations should be given to the infections produced by biofilm producing bacteria $[5,12,14]$. Generally, staphylococcal strains, which produce biofilm, lead to chronic mastitis after unsuccessful treatment, especially with beta-lactam antibiotics in dairy animals $[2,7,31]$.

Other author in his study of staphylococci isolated from mastitis milk in cows reported that the biofilm production and resistance to antibiotics were most frequently virulence factors in strains isolated from clinical IMI. Increasing biofilm production was evident in strains from repeat and chronic cases of mastitis [15]. Similar study report, that the production of biofilm was determining factor of pathogenity of S. epidermidis in hospital infections, what has been confirmed in 3 isolates in our study [21].

\section{CONCLUSION}

The study showed that most frequently isolated udder pathogens were CoNS, followed S. aureus, E. coli and streptococci. Coagulase negative staphylococci such as $S$. chromogenes, S. warneri and S. xylosus isolated from clinical mastitis indicated highest degree of pathogenity in production of more virulence factors (lysines, DNAse, gelatinase, biofilm). On the significance level of $\alpha=0.05$ the dependence the production of virulence factors in the four most frequently isolated staphylococci on type of mastitis in cows was rejected. From the results manifests that the impact of CoNS is increasing on the occurrence of IMI, probably because prevalence of others major pathogens (Str. agalactiae or Str. dysgalactiae) is decreasing. In order to reduce occurrence and resistance of bacterial agents causing the predominantly chronic IMI, it is necessary to base the obtained antibiogram results on monitored farms as well as selective therapy of dairy cows during dry period.

\section{ACKNOWLEDGMENTS}

This research was supported by the Slovak grants KEGA no. 009UVLF-4-2021, and VEGA no. 1-0529-19. 


\section{REFERENCES}

[1] Čobirka M, Tančin V, Slama P. 2020.” Epidemiology and Classification of Mastitis”. Animals. vol. 10, p. 2212.

[2] orti S, Sicher D, Regli W, Stephan R. 2003. "Current data on antibiotic resistance of the most important bovine mastitis pathogens in Switzerland". Schweiz Arch. Tierheilkd. vol. 145, pp. 571-575.

[3] Dufour S, Labrie J, Jacques M. 2019. “The Mastitis Pathogens Culture Collection”. Microbiol Resour Announc. vol. 8, no. 15: e00133-19.

[4] El-Diasty, M., Talaat, H., Atwa, S., Elbaz, E., Eissa, M. 2019. Occurrence of Coagulase-negative Staphylococcal mastitis in dairy cows. Mansoura Veterinary Medical Journal. vol. 23. p. 35-39. DOI: 10.35943/mvmj.2019.23.207

[5] Fredheim E.G.A, Klingenberg C, Rodhe H, Frankenberger S, Gaustad P, Flaegstad T, Sollid J.E. 2009. "Biofilm formation by Staphylococcus haemolyticus". J. Clin Microbiol. vol. 47, pp. 1172-80.

[6] Fox L.K, Gay J.M. 1993." Contagious mastitis". The Veterinary clinics of North America. Food Animal. Vol. 9, pp. 475-87.

[7] Gentilini E, Denamiel G, Betancor A, Rebuelto M, Fermepin M.R, De Torrest RA. 2002. "Antimicrobial susceptibility of coagulase-negative staphylococci isolated from bovine mastitis in Argentina". J. Dairy Sci., vol. 85, pp. 1913-1917.

[8] Haveri M, Roslöf A, Pyörälä S. 2007. "Virulence genes of bovine Staphylococcus aureus from persistent and nonpersistent intramammary infections with different clinical characteristics". J Appl Microbiol. vol. 103, pp. 993-1000.

[9] Hiko A. 2019. "Isolation, DNase-cross-Coagulase test and antimi-crobial resistance test on Staphylococcus along beef abattoir line in Addis Ababa Ethiopia". Ethiop. Vet. J., vol. 23, no.1, pp. 90 - 110.

[10] Holko I, Tančin V, Vršková M, Tvarožková K. 2019. "Prevalence and antimicrobial susceptibility of udder pathogens isolated from dairy cows in Slovakia". Journal of Dairy Research. pp. $1-4$.

[11] Idriss S.E, Tančin V, Foltýs V, Kirchnerová K, Tančinová D, Vršková M. 2013. "Relationship between mastitis causative pathogens and somatic cell count in milk of dairy cows". Slovak Journal of Food Sciences, vol. 7, no. 1, pp. 207-212.

[12] Isaac P, Bohl L.P, Breser M.L, Orellano M.S, Conesa A, Ferrero M.A, Porporatto C. 2017. "Commensal coagulasenegative Staphylococcus from the udder of healthy cows inhibits biofilm formation of mastitis-related pathogens". Vet Microbiol. vol. 207, pp. 259-266.

[13] Kabrt M. (2013). “Aplikovaná statistika: Test chí-kvadrát nezávislosti v kontingenční tabulce”. [online]. Dostupné z: http://www.milankabrt.cz/testNezavislosti/

[14] Marques V.F, da Motta C.C, Soares B.S, de Melo D.A, de Oliveira C.S.H, Coelho I.S, Santos H.B, de Souza M.M.S. 2017. "Biofilm production and beta-lactamic resistance in Brazilian Staphylococcus aureus isolates from bovine mastitis". Brazilian Journal of Microbiology. vol. 48, no 1, pp. 118-124.

[15] Melchior M.B, Vaarkamp H, Fink-Gremmels J. 2006. "Comparative assessment of the antimicrobial susceptibility of Staphylococcus aureus isolates from bovine mastitis in biofilm versus planktonic culture". Journal of Veterinary Medicine B, Infectious Diseases and Veterinary Public Health, vol. 53, pp. 326-332.

[16] Moniri R, Dastehgoli K, Akramian A. 2007. "Increasing resistant CNS in bovine clinical mastitis"s. Pakistan J Biolog Sci. vol. 10, no. 15, pp. 2465-2469.

[17] Monistero V, Graber H.U, Pollera C, et al. 2018. Staphylococcus aureus Isolates from Bovine Mastitis in Eight Countries: Genotypes, Detection of Genes Encoding Different Toxins and Other Virulence Genes. Toxins (Basel). Vol. 10, no. 6 , p. 247.

[18] Nascimento J.S, Fugundes P.C, Brito A.V, Dos Santos K.R, Bastos M.C. 2005. "Production of bacteriocins by coagulase-negative staphylococci involved in bovine mastitis". Veterinary Microbiology, vol. 106, pp. 61-71.

[19] National mastitis council. 2001. National Mastitis Council Recommended Mastitis Control Program. Natl. Mastitis Counc. Ann. Mtg. Proc., Reno, NV. Natl. Mastitis Council, Inc., Verona, WI. 408 p. ISBN 978-0-309-06997-7.

[20] Notcovich S, DeNicolo G, Flint S.H, et al. 2018. "Biofilm-Forming Potential of Staphylococcus aureus Isolated from Clinical Mastitis Cases in New Zealand". Vet Sci. vol. 5, no. 1, p. 8.

[21] Otto M. 2004. "Virulence factors of the coagulase-negative staphylococci”. Front. Biosci. vol. 9, pp. 841-863.

[22] Otto M. 2018. "Staphylococcal Biofilms". Microbiol Spectr. vol. 6, no. 4, p. 1-26.

[23] Pyörälä S, Taponen S. 2009. "Coagulase-negative staphylococci - Emerging mastitis pathogens. Veterinary Microbiology, vol. 134, no. 1-2, p. 3-8. https://doi.org/10.1016/j.vetmic.2008.09.015

[24] Supre K, Haesebrouck F, Zadoks R.N, Vaneechoutte M, Piepers S, De Vliegher S. 2011. "Some coagulase-negative Staphylococcus species affect udder health more than others". J. Dairy Sci., vol. 94, pp. 2329-2340.

[25] Tančin V. 2013. "Somatic cell counts in milk of dairy cows under practical conditions". Slovak Journal of Animal Science, vol. 46, no. 1, pp. 31-34. 
[26] Tančin V, Mikláš Š, Čobirka M, Uhrinčat' M, Mačuhová L. 2020. "Factors affecting raw milk quality of dairy cows under practical conditions". Slovak Journal of Food Sciences, vol. 14, pp. 744-749.

[27] Tvarožková K, Tančin V, Holko I., Uhrinčat' M, Mačuhová L. 2019. "MASTITIS IN EWES: somatic cell counts, pathogens and antibiotic resistance”. Journal of Microbiology, Biotechnology and Food Sciences. vol. 9, no. 3, pp. 661670

[28] Tvarožková K, Tančin V, Uhrinčat' M, Hleba L, Mačuhová L. 2020. "Mastitis pathogens and somatic cell count in ewes milk". Slovak Journal of Food Sciences Vol. 14, pp. 164-169.

[29] Vasil' M, Elečko J, Zigo F, Farkašová Z. 2012. “Occurrence of some pathogenity factors in coagulase negative staphylococci isolated from mastitis milk in dairy cows". Slovak Journal of Food Sciences. vol. 6, no. 2, pp. 60-63.

[30] Vasil’ M, Farkašová Z, Elecko J, Illek J, Zigo F. 2017. “Comparison of biofilm formation by Staphylococcus aureus and Staphylococcus epidermidis strains isolated from sheep milk using three diagnostic methods". Polish J. of Vet. Sci. Vol. 20, pp. 795-801.

[31] Vinodkumar K., Neetha, N, Ashok S, Suchithra S, Justin D, Radhik S. 2017. "Genotypic and phenotypic $\beta$-lactam resistance and presence of PVL gene in Staphylococci from dry bovine udder”. PLOS ONE. vol. 12. e0187277.

[32] Zigo F, Sasáková N, Gregová G, Výrostková J, Ondrašovičová S. 2020. “Effects of Using an Alternative Bedding Composition on the Levels of Indicator Microorganisms and Mammary Health in Dairy Farm Conditions". Agriculture, vol. 10, p. 245. 